\title{
Purification of Potato Virus Y for Polyclonal Antisera Production and Assessment of Antisera Specificity through DAS-ELISA
}

\author{
Ranima Mishra $^{1^{*}}$, P.D. Nath ${ }^{1}$, B. Raigond ${ }^{2}$, R.C. Boro ${ }^{3}$, \\ Shankar Hemanta Gogoi ${ }^{1}$ and Jutimala Phookan ${ }^{1}$
}

${ }^{1}$ Department of Plant Pathology, ${ }^{3}$ Department of Agricultural Biotechnology, Assam Agricultural University, Jorhat 785013, Assam, India

${ }^{2}$ Division of Plant Protection, ICAR-Central Potato Research Centre (CPRI), Shimla, Himachal Pradesh, India

*Corresponding author

\section{A B S T R A C T}

\begin{tabular}{|l|}
\hline Ke y w or d s \\
DAS-ELISA, \\
$\begin{array}{l}\text { Purification, } \\
\text { Polyclonal antisera, } \\
\text { Potato virus Y }\end{array}$ \\
\hline Article Info \\
\hline $\begin{array}{l}\text { Accepted: } \\
\text { 08 July 2018 } \\
\text { Available Online: } \\
\text { 10 August } 2018\end{array}$ \\
\hline
\end{tabular}

Purified viral protein was obtained from Potato virus $Y$ (PVY) pure culture maintained on potato (Solanum tuberosum L.) plants. The average concentration of the purified materials was found to be $153.1 \mathrm{ng} / \mu \mathrm{l}$. PVY purified virus preparation was used for immunizing rabbit for production of polyclonal antisera against the virus. Good quality antisera were collected one week post boosters (AS4b, AS5b, AS6b and AS7b) and the IgG fractions were separated through ammonium sulphate precipitation. These four IgG fractions were tested for the detection of PVY by DAS-ELISA with universal anti- rabbit enzyme conjugate as secondary antibody, resulted high specificity with the known PVY infected samples. The assay was compared with the commercial DAS-ELISA kit (Bio Reba, AG, Switzerland). Results revealed that, among the antisera; AS6b was showing the highest mean absorbance values for all positive samples (2.210) and the value shown by the commercial kit was slightly higher i.e., 2.250 and these were followed by AS5b (1.680), AS7b (0.929) and AS4b (0.362), respectively. The absorbance values shown by AS6b were statistically at par with the commercial kit.

\section{Introduction}

Potato (Solanum tuberosum L., family: Solanaceae); recognized as the 'king of vegetables', had been cultivated in almost all the states of India under diverse agro-climatic conditions. India is an important potato producing country with an area estimated to be around 20.64 lakhs ha and production of 455.99 lakh MT during 2015-16 (Anon.,
2016) and Assam has marked its place among the top potato producing states within the country; ranked seventh, with a total potato production of 975.27 thousand tonnes. In Assam, 99.7 hectares of land is subjected to potato cultivation producing a total yield of 9.7 tonnes (Anon., 2018).

Viral diseases were responsible for degeneration of potato cultivars, indicated by 
decrease in vigour, productivity of the crop and resistance to diseases after successive cultivation from the same lot of tubers (Nascimento et al., 2003). Potato virus Y (PVY) was one of the most common and the most dangerous virus found in potato, distributed world-wide, causing losses in the form of reduced yield or quality of potato crop as well as seed tuber, which is an important factor for yield of potato causing as much as 50 to 80 per cent yield loss in heavily infected commercial lots (Hane and Hamm, 1999; Nascimento et al., 2003; Biswas et al., 2005 and Folwarczna et al., 2008).

Potato virus $Y$, the most dangerous virus in potato fields causing the disease common mosaic or potato severe mosaic had been one of the most serious problems faced by potato growers worldwide (Nolte et al., 2009). PVY was also reported as an important viral pathogen of potato crop in Jorhat district of Assam with an incidence of 33.95 per cent (Mishra and Nath, 2015).

As the virus affects tuber quality, therefore, production of disease free planting materials had been one of the most important factors for certification of potato tubers. Early detection and identification of the virus in the field is the need of the hour, for production of healthy crop lot. Therefore, efficient virus detection methods play an important role in producing and utilizing certified seed potatoes with minimum virus infection and Enzyme linked immunosorbent assay (ELISA) using specific antisera has been one of the most common method for the detection of potato viruses (Sankari et al., 2007).

Hence, the present study was carried out where we reported the production of polyclonal antisera against PVY in Jorhat district of Assam from North- East India for the first time and their specificity were confirmed by testing with PVY infected samples collected from the district. The assay was compared with PVY commercial DASELISA kit (Bio-Reba, AG, Switzerland) as control using the same healthy and PVY infected plant samples.

\section{Materials and Methods}

Potato virus $Y$ (PVY) isolates were maintained in vitro on its host Potato (Solanum tuberosum L.). These plants were maintained in the green house of the ICAR-Central Potato Research Centre (CPRI), Shimla, Himachal Pradesh (Fig. 1). The leaves from those potato plants were used as the virus source for purification. Purification was done according standard protocol (Khurana et al., 1987). Four hundred grams of leaves from those PVY infected potato plants were collected and kept in ice water for one hour. Afterwards, leaves were extracted in $0.1 \mathrm{M}$ phosphate and sodium buffer, pH-7.0 with $0.1 \%$ of 2mercaptoethanol, $0.1 \%$ DEECA and $0.015 \mathrm{M}$ of EDTA with ratio of $1: 2$. The sap was then transferred to $2 \mathrm{ml}$ microfuge tubes and centrifuged at $7800 \mathrm{rpm}$ for 30 minutes. The pellet was removed and equal volume of chloroform $\left(\mathrm{CHCl}_{3}\right)$ : carbon tetrachloride $\left(\mathrm{CCl}_{4}\right) \quad(1: 1$ ratio) was added to the supernatant. Afterwards, $40 \%$ polyethylene glycol (PEG 6000) and 0.2 mol sodium chloride $(\mathrm{NaCl})$ were added and stirred at $4{ }^{\circ} \mathrm{C}$ for 60 minutes and incubate at $4^{\circ} \mathrm{C}$ for 60 minutes. This was then centrifuged at 7500 rpm for 25 minutes and the supernatant was collected. This was again centrifuged at 2500 for 10 minutes and the pellet was removed. Afterwards, the supernatant was processed by adding $1 \%$ of triton- 100 and stirred at $4{ }^{\circ} \mathrm{C}$ for 120 minutes and precipitates at $10000 \mathrm{rpm}$ for 30 minutes. After removal of the supernatant, the pellet was processed with the $0.01 \mathrm{~m}$ sodium $(\mathrm{Na})$ and potassium $(\mathrm{K})$ phosphate buffer, $\mathrm{pH}-7.0$ with $0.5 \mathrm{M}$ urea and $0.1 \% 2$ mercaptoethanol (1/10) of the original volume and kept at $4^{\circ} \mathrm{C}$ for overnight. Clarification 
was done at $10000 \mathrm{rpm}$ for 10 minutes to remove the pellet. The supernatant was processed to centrifuge on sucrose cushion $30 \%(\mathrm{~W} / \mathrm{V})$ (density gradient) in $0.01 \mathrm{M}$ sodium $(\mathrm{Na})$ and potassium $(\mathrm{K})$ phosphate buffer $\mathrm{pH}-7.0$ (15ml of sample for $5 \mathrm{ml}$ sucrose at $30 \%$ ) at $25000 \mathrm{rpm}$ for 150 minutes in ultra-centrifuge to get the viral protein as pellet. Titre of purified viral suspension was measured through nanodrop quantification.

PVY purified virus preparation was used for immunizing rabbit for production of antisera. Rabbit was immunized subcutaneously, similar to Nath (2000), at two weeks interval for the first three injections and after these; four boosters were given at six weeks intervals. Bleeds were taken one week after each injection. Immunoglobulins ( $\mathrm{IgG}$ ) were purified by the ammonium sulphate precipitation and titres were measured through nanodrop quantification. The antisera from the booster injections were designated as AS4b, AS5b, AS6b and AS7b.

IgG from the booster antisera were tested for their sensitivity and specificity against known PVY healthy and infected plant samples in DAS- ELISA and the assay was compared with PVY commercial DAS- ELISA kit (BioReba, AG, Switzerland) as control using the same healthy and PVY infected plant samples. DAS- ELISA was carried out as per standard protocol (Fig. 2) and the antisera (as primary IgG) were used with the PVY antibodyalkaline phosphatase conjugate from Bio Reba, AG, Switzerland; in the assay. The assay was quantitative, replicated five times and every time saps from both healthy and infected plants were taken in the study.

\section{Statistical analysis}

Completely randomized design (CRD) analysis was done to calculate out the critical difference (CD) among the tested antisera
(IgG batches from booster injections) and the PVY commercial IgG for their specificity in the DAS- ELISA assay with healthy and PVY infected leaf extracts.

\section{Results and Discussion}

The purification was done in two batches. The absorbance values of the two batches of purified material were found as 1.19 and 1.38, respectively, at $260 \mathrm{~nm}$, while the absorbency at $280 \mathrm{~nm}$ were found as 1.02 and 1.07 for both the batches, respectively.

The average concentration of the purified materials was found to be $153.1 \mathrm{ng} / \mu \mathrm{l}$.

The antisera recovered following the first three injections showed very low absorbance values and hence, were not considered for further serodiagnostic assays. Among the antisera from the booster doses, AS6b (antisera obtained after third booster injection) showed the highest absorbance value; viz., $1.44 \mathrm{mg} / \mathrm{ml}$ at the wave length of $280 \mathrm{~nm}, 26$ weeks after first injection which was followed by AS5b, AS7b and AS4b (Fig. 3).

The four batches of antisera, from the booster injections, viz.; AS4b, AS5b, AS6b and AS7b, were tested for their sensitivity against PVY in DAS- ELISA assay with five replications maintaining both primary and secondary antibody dilutions at $10^{-3}$. The assay was compared with PVY commercial DASELISA kit (Bio-Reba, AG, Switzerland) as control using the same healthy and PVY infected plant samples. All the antisera could successfully detect PVY in the potato leaf extracts. Among the produced antisera AS6b was showing the higher absorbance values for the leaf extracts which were at par with the PVY commercial IgG from the kit followed by AS5b, AS7b and AS4b. These results reflected high sensitivity as well as specificity of the antisera batches against PVY. 
Fig.1 Potato virus $Y$ (PVY) isolates maintained in vitro on its host plant Potato (Solanum tuberosum L.). (a) PVY infected potato plants maintained as virus source in the green house (b) collection of leaf samples from PVY infected potato plants for virus purification

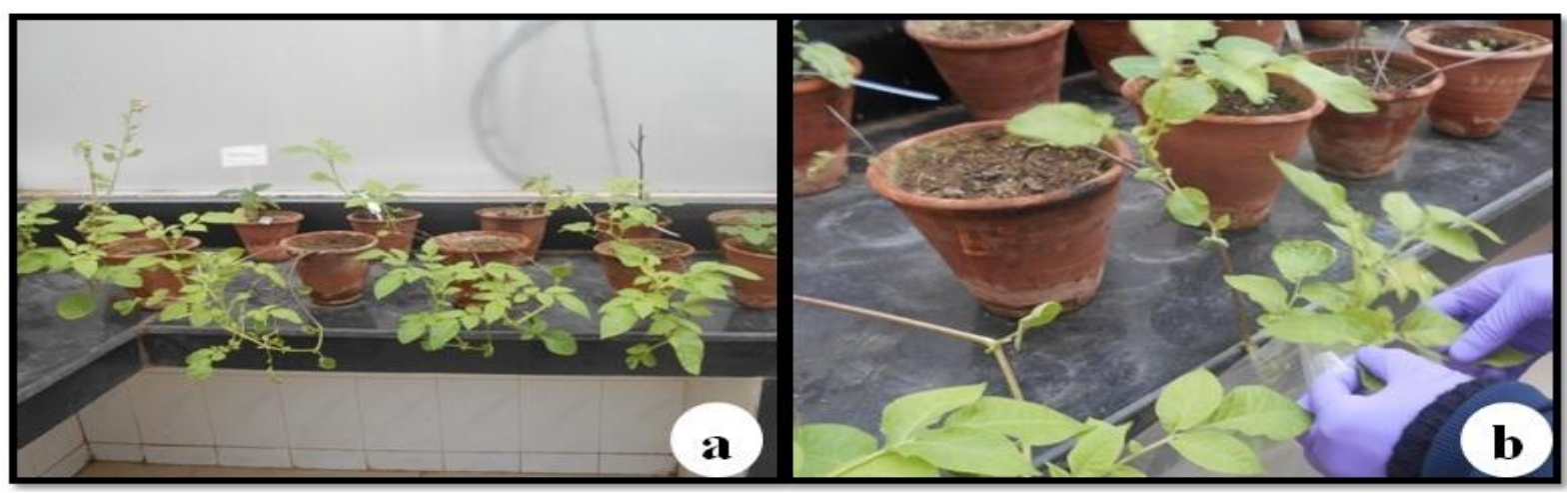

Fig.2 DAS- ELISA assay with produced antisera and comparison with PVY commercial kit. (a) sensitization of plate with addition of $\mathrm{IgG}$, (b) addition of homogenized sample, (c) addition of IgG conjugated, (d) IgG enzyme- conjugate giving a colour reaction in presence of its substrate

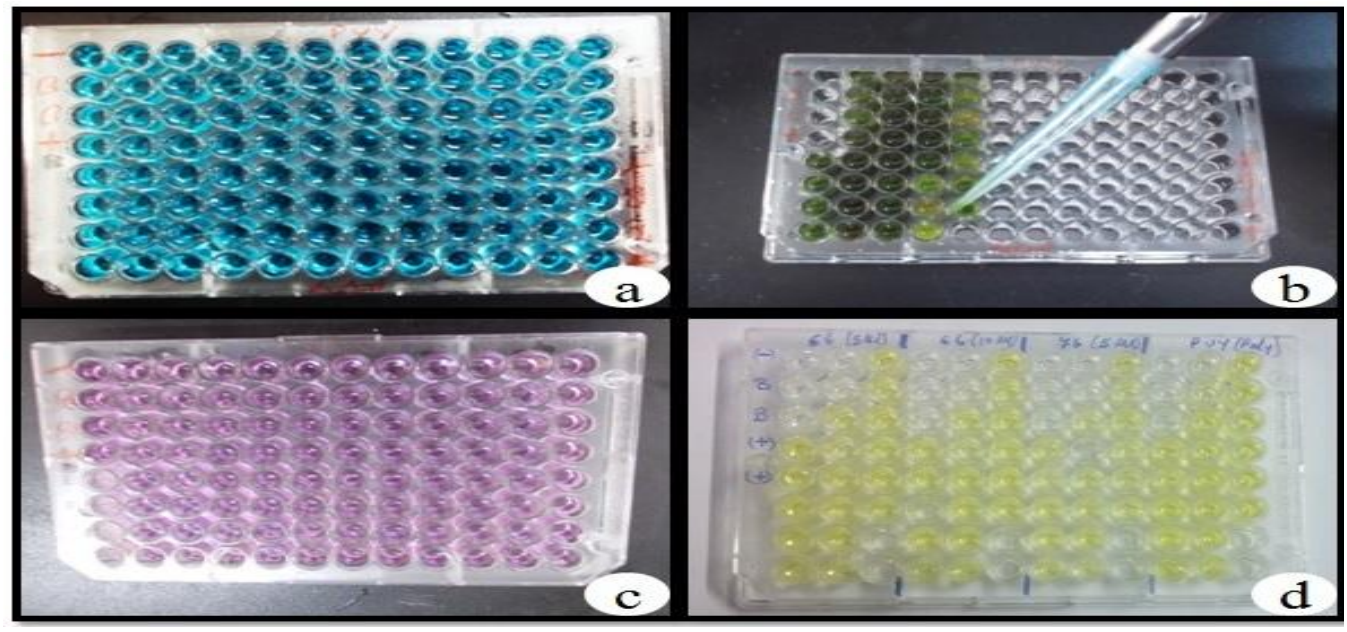

Fig.3 Absorbance $\left(\mathrm{OD}_{280}\right)$ values for PVY antisera batches from booster injections in nanodrop quantification

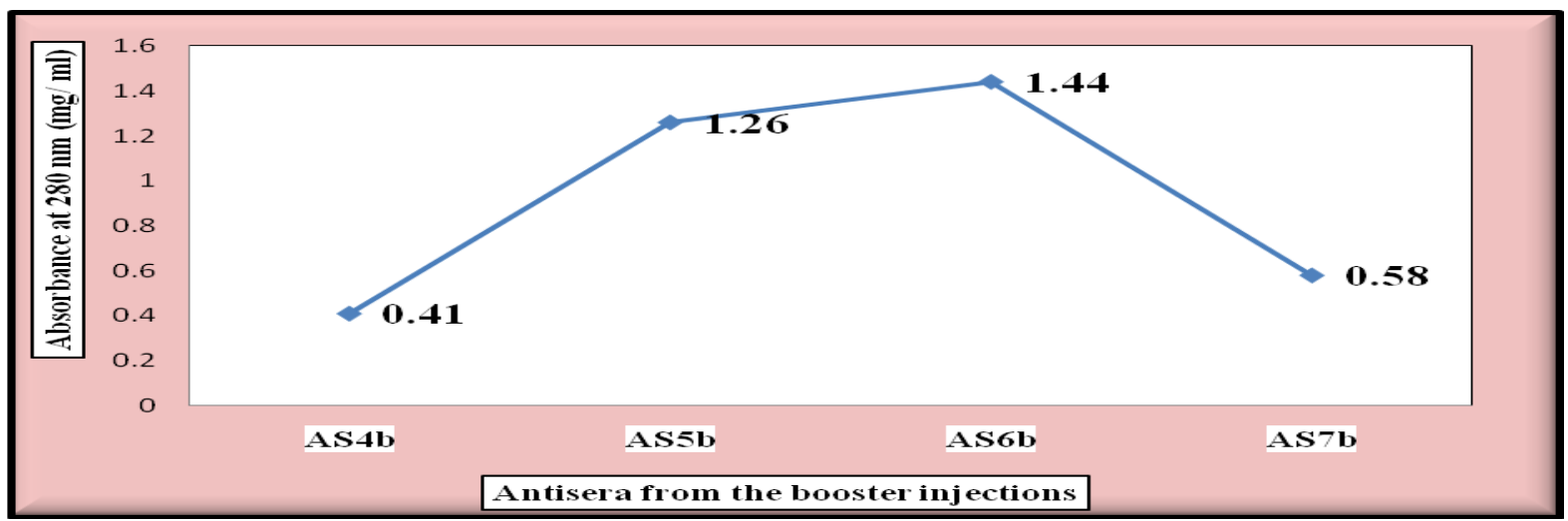


Table.1 DAS- ELISA values for leaf extracts of potato samples

\begin{tabular}{|c|c|c|c|c|}
\hline Antisera & $\begin{array}{c}\text { ELISA value for } \\
\text { positive control }\end{array}$ & $\begin{array}{c}\text { Minimum } \\
\text { ELISA value }\end{array}$ & $\begin{array}{c}\text { Maximum } \\
\text { ELISA } \\
\text { value }\end{array}$ & $\begin{array}{c}\text { Mean ELISA for all } \\
\text { positive samples }\end{array}$ \\
\hline AS4b & 0.077 & 0.097 & 0.727 & 0.362 \\
\hline AS5b & 0.512 & 1.062 & 1.950 & 1.680 \\
\hline AS6b & 0.740 & 1.480 & 2.850 & 2.210 \\
\hline AS7b & 0.303 & 0.520 & 1.776 & 0.929 \\
\hline $\begin{array}{c}\text { PVY } \\
\text { (commercial kit) }\end{array}$ & 0.991 & 1.592 & 2.990 & 2.250 \\
\hline $\mathbf{C D}(\mathbf{P = 0 . 0 5 )}$ & & & & 0.236 \\
\hline
\end{tabular}

Table.2 Duncan's Multiple Range Test (DMRT) between antisera batches and PVY (Commercial kit) DAS- ELISA values

\begin{tabular}{|c|c|c|c|c|c|}
\hline \multirow[t]{2}{*}{ IgG } & \multicolumn{4}{|c|}{ Subset } & \multirow[b]{2}{*}{$\begin{array}{c}\text { PVY } \\
\text { (Commercial kit) }\end{array}$} \\
\hline & AS4b & AS7b & AS5b & AS6b & \\
\hline AS4b & $0.348^{\mathrm{d}}$ & & & & \\
\hline AS7b & & $0.898^{\mathrm{c}}$ & & & \\
\hline AS5b & & & $1.626^{\mathrm{b}}$ & & \\
\hline AS6b & & & & $2.144^{\mathrm{a}}$ & \\
\hline $\begin{array}{c}\text { PVY } \\
\text { (Commercial kit) }\end{array}$ & & & & & $2.193^{\mathrm{a}}$ \\
\hline Significance & 1.000 & 1.000 & 1.000 & 1.000 & 1.000 \\
\hline
\end{tabular}

*Means for groups in homogeneous subsets are displayed

The absorbance values $\left(\mathrm{OD}_{405}\right)$ for extracts of potato leaf tissues were recorded by comparing the absorbance values for negative control and the positive control. A value which was five times higher than the average of negative controls, considered as positive. Results revealed that, among the antisera; AS6b was showing the highest mean absorbance values for all positive samples (2.210) and the value shown by the commercial kit for the same was slightly higher; i.e., 2.250. These were followed by AS5b (1.680), AS7b (0.929) and AS4b (0.362), respectively (Table 1 ).

Critical difference (CD) among the four $\operatorname{IgG}$ batches and PVY commercial IgG was calculated out by completely randomized design (CRD) analysis for their specificity against PVY. The absorbance values shown by AS6b were statistically at par with the commercial kit (Table 2). These results reflected high sensitivity as well as specificity of the antisera batches against PVY.

All the four antisera batches from the booster injections showed highly sensitive and specific reaction against PVY in DASELISA assay. AS6b showed the highest sensitivity with the maximum DAS- ELISA value followed by AS5b and AS7b respectively compared with the commercial kit. High quality antisera could be produced through rabbit immunizations against PVY. 
This can be carried out for different viruses of quarantine importance which will further help in early detection and identification, certification of disease free planting material as, early detection helps in management at appropriate time.

\section{References}

Anonymous. (2016). A brief report on potato production in the country. National Horticultural Research and Development Foundation. http://nhrdf. org/pdf/POTATO\%20CROP\%20REPO RT- \%2008\%20APRIL \%20 2016.pdf. Retrieved on 18.04.2018.

Anonymous. (2018). Top 10 largest potato producing states in India in 2018. www.thedailyrecords.com. Retrieved on 18.04.2018.

Biswas M K, De BK and Nath PS. 2005. Rate of spread of PVX, PVY and PLRV diseases to potato varieties. Ann Plant Prot Sci. 13:165-178.

Folwarczna J, Plchova $\mathrm{H}$, Moravec $\mathrm{T}$, Hoffmeisterova H, Dedic P, Cerovska N. 2008. Production of polyclonal antibodies to a recombinant coat protein of Potato virus Y. Folia Microbiol. 53 (5): 438- 442.

Hane DC and Hamm PB. 1999. Effects of seed borne Potato virus $Y$ infection in two potato cultivars expressing mild symptoms. Plant Dis. 83: 43- 45.

Khurana SMP, Singh MN and Kumar S. 1987. Purification of Potato Virus $Y$ and the production of antiserum. Curr Sci. 56: 420- 422.

Mishra R and Nath PD. 2015. Incidence and detection of Potato virus $Y$ on potato crop in Jorhat district of Assam by DAS-ELISA. Indian Phytopath. 68 (4): 467- 469.

Nascimento LC, Pio-Riberio G, Willadino L and Andrade GP. 2003. Stock indexing and Potato Virus $\mathrm{Y}$ elimination from potato plants cultivated in vitro. Scientia Agricola. 60: 525- 530.

Nath, P.D. (2000). Studies on Rice Tungro disease with special reference to purification, serology and molecular mapping of resistance to Rice Tungro Spherical Virus. Ph. D. thesis submitted to Assam Agricultural University. Assam.

Nolte, P., Alvarez, J.M. and Whitworth, J.L. 2009. Potato virus $Y$ management for the seed potato producer. Extension Bulletin. University of Idaho. pp. 1-8.

Sankari S, Ali MC and Katayama K et al., 2007. The first report of polyclonal antibody production of a Syrian isolate of Potato virus Y. J Agric Sci. 52 (2): 109- 114.

\section{How to cite this article:}

Ranima Mishra, P.D. Nath, B. Raigond, R.C. Boro, Shankar Hemanta Gogoi and Jutimala Phookan. 2018. Purification of Potato Virus Y for Polyclonal Antisera Production and Assessment of Antisera Specificity through DAS-ELISA. Int.J.Curr.Microbiol.App.Sci. 7(08): 1311-1316. doi: https://doi.org/10.20546/ijcmas.2018.708.148 